\title{
LA INSUFICIENCIA DE LA REGULACIÓN EUROPEA SOBRE LOS LÍMITES DE LA PUBLICIDAD COMERCIAL
}

\author{
Daniel Capodiferro Cubero
}

doi: http://dx.doi.org/10.18543/ed-65(1)-2017pp15-43

\begin{abstract}
SuMARIO: 1. MARCO GENERAL. 2. LA INADECUACIÓN DEL CONCEPTO DE CONSUMIDOR PARA DEFINIR AL SUJETO PROTEGIDO POR LAS NORMAS SOBRE PUBLICIDAD EN EL DERECHO COMUNITARIO. 3. LA PROTECCIÓN GENÉRICA FRENTE A LA PUBLICIDAD DESLEAL. 4. LAS GARANTÍAS FRENTE A LAS COMUNICACIONES PUBLICITARIAS AUDIOVISUALES. 5. LA PUBLICIDAD DESARROLLADA A TRAVÉS DE INTERNET. 6. PREVISIONES ESPECÍFICAS PARA LA PROTECCIÓN DE LOS MENORES DE EDAD. 7. VALORACIONES FINALES.
\end{abstract}

\section{MARCO GENERAL}

El art. 26.1 del Tratado de Funcionamiento de la Unión Europea (TFUE) encomienda a ésta tanto el establecimiento como la garantía del correcto funcionamiento del mercado interior de conformidad con las disposiciones pertinentes de los Tratados. Lejos de ser una simple habilitación para dictar normas relativas a la defensa de la libre competencia, el desarrollo de este precepto requiere que se tenga también en cuenta la posición, en cada una de las fases de la actividad económica y comercial, de los consumidores, cuya protección ha ido concibiéndose de manera progresiva en el ámbito comunitario como un instrumento cada vez más necesario para la integración europea y la consolidación del mercado interior ${ }^{1}$.

${ }^{1}$ E.F. PÉrez CARrillo, «La política europea de consumidores: entre la revisión de 2001 y la ampliación de la Unión», Estudios sobre consumo, n. ${ }^{\circ} 63$ (2002): 55. 
También el art. 12 TFUE menciona entre los intereses transversales de las políticas comunitarias la protección de los consumidores, por lo que éste principio no sólo deberá tenerse en cuenta en la definición y en la ejecución de aquellas, ya sea por parte de la propia Unión como de los Estados miembros, sino ser objeto de actuaciones específicas de defensa activa y promoción por parte de las instituciones comunitarias ${ }^{2}$. En términos más generales, el art. 38 de la Carta de los Derechos Fundamentales de la Unión Europea (CDFUE) se vuelve a referir a los consumidores al establecer que las políticas de la Unión deberán garantizarles un alto nivel de protección; esto, al contrario de lo que pudiera parecer en un primer momento, no constituye el reconocimiento para los consumidores europeos de un derecho fundamental a obtener protección, sino una manera de reforzar esta premisa como principio inspirador para las instituciones europeas en el marco de las competencias que tienen atribuidas ${ }^{3}$. No obstante, ambas menciones normativas permiten identificar la vigencia de un interés preferente de estos que debe ser tenido en cuenta por parte de los creadores y aplicadores del Derecho Comunitario como un objetivo de interés público que requiere la intervención de la Administración para su consecución. A ese nivel se pueden llegar a reconocer verdaderos derechos de los ciudadanos en relación a su intervención en el mercado de productos y servicios que sirvan para compensar posibles excesos causados por la liberalización de éste, a la que se orientan las disposiciones del Derecho Comunitario. Considerando que la protección de los consumidores se define en el art. 4.2.f) TFUE como una materia de competencia compartida con los Estados Miembros, la Unión Europea podrá dictar para el cumplimiento de este objetivo tanto Directivas para la homogeneización de las distintas legislaciones nacionales como medidas propias que sirvan de apoyo, complemento y supervisión de aquellas adoptadas por los Estados, que retienen la capacidad para aumentar la protección dispensada por el Derecho Comunitario mientras lo hagan de modo compatible con los Tratados.

La articulación normativa de esta cuestión en el Ordenamiento Comunitario abarca una enorme cantidad de materias específicas, entre las que se encuentra, objeto de un tratamiento propio en varias disposiciones, la publicidad. En un sistema de libre mercado que en última instancia debería estar basado en la información ideal, la salvaguarda de la veracidad de las comunicaciones entre oferentes de bienes y servicios y posibles destinatarios

2 Vid. A. BAR CENDÓN, «La Unión Europea como unión de valores y derechos: teoría y realidad», Teoría y Realidad Constitucional, n. ${ }^{\circ} 33$ (2014): 104.

${ }_{3}$ M. López Escudero, «Título IV. Solidaridad», en Carta de los Derechos Fundamentales de la Unión Europea. Comentario artículo por artículo, ed. por MANGAS MARTín (coord.), (Madrid: Fundación BBVA, 2008), 634. 
constituye un elemento esencial para su correcta implementación que, en última instancia, sirve para evitar perturbaciones en el proceso económico 4 . De ahí que previsiones para la protección de los consumidores también deban proyectarse y alcanzar a los mensajes publicitarios.

Con independencia de las diferentes denominaciones que esta actividad recibe en las distintas normas, la publicidad comercial se puede definir como la comunicación establecida entre un oferente de bienes y servicios, con intención de promocionarlos, y todos aquellos destinatarios a los que alcance, caracterizándose por su finalidad persuasiva e interesada, que se alcanza mediante la combinación de hechos, ideas u opiniones a las que se añade un componente creativo ${ }^{5}$, resultando indiferente que se dirija a un colectivo amplio o a un único destinatario ${ }^{6}$, o el formato comunicacional mediante el que se materialice. Se trata de una actividad destinada a favorecer la comercialización de productos y servicios, que sirve para relacionar a los anunciantes, emisores de un mensaje que tiene como finalidad promover la contratación ${ }^{7}$, con los ciudadanos, los receptores de éste, con el fin de hacerles llegar una información sobre productos y servicios a su alcance que influya en sus decisiones de consumo ${ }^{8}$, lo que la convierte en un elemento inseparable del propio funcionamiento de cualquier mercado. Por esta razón, la coordinación de las distintas legislaciones sobre publicidad se presenta, en última instancia, como una exigencia de los principios de libre circulación de servicios y mercancías consagrados en el Tratado de la Unión Europea9

Pero por otro lado, como forma de comunicación, y con independencia de su evidente vinculación con la libertad de empresa, la actividad publicitaria se puede considerar también una materialización de las libertades de expresión e información. Conforme estableció en su momento el Tribunal Europeo de Derechos Humanos, cuya jurisprudencia sirve para determinar el alcance de los derechos garantizados en la $\mathrm{CDFUE}^{10}$, la finalidad de la comunicación

${ }^{4}$ A. Descalzo González, Principio de veracidad y politica pública en el mercado de la publicidad comercial, (Madrid: Dykinson, 2003), 235-236.

5 J.M. De la Cuesta Rute, Curso de Derecho de la Publicidad, (Pamplona: EUNSA, 2002), 45 y s.

${ }^{6}$ P.A. De Miguel Asensio, Régimen jurídico de la publicidad transfronteriza, (Madrid: Iustel, 2005), 40.

7 S. Vilajoana Alejandre y J. Cuerva de Cañas, ¿Cómo aplicar los límites jurídicos de la publicidad?, (Barcelona: UOC, 2015), 36.

${ }^{8}$ C. CAMACHO PEREIRA, La protección del consumidor frente al mensaje publicitario, (Cizur Menor: Thomson Reuters-Aranzadi, 2012), 54.

9 A. Azurmend, Derecho de la comunicación, (Barcelona: Bosch, 2011), 316.

${ }^{10}$ Conforme a las Explicaciones sobre la Carta de los Derechos Fundamentales, documento 2007/C 303/02, publicado en el D.O., Serie C, n. ${ }^{\circ}$ 303/17, de 14 de diciembre de 2007, la referencia que el art. 52 CDFUE contiene al CEDH para fijar el sentido y el al- 
no es relevante para considerar su subsunción dentro del ámbito objetivo de las libertades del art. $10 \mathrm{CEDH}$. Por ello, se debe considerar que éstas amparan cualquier mensaje de cualquier sujeto aunque su motivación sea el ánimo de lucro o se trate de información comercial ${ }^{11}$, sin que tampoco parezca importar el hecho de la nula relevancia que ésta presenta para la libre formación de la opinión pública ${ }^{12}$. Así entendida, la existencia de una libertad de expresión publicitaria implica como correlato, al igual que sucede con el régimen general, la presencia de una serie de derechos de los destinatarios de los mensajes que deberían ser garantizados, llegando incluso a constituir límites para su ejercicio, con independencia del efecto que el mensaje tenga sobre su comportamiento económico.

No obstante, la Unión Europea ha venido manteniendo un enfoque esencialmente mercantil sobre la actividad publicitaria ${ }^{13}$, centrando su regulación en la incidencia que ésta puede tener sobre los aspectos económicos y mercantiles de la actuación del consumidor. En consonancia con el ámbito sobre el que la Unión Europea es competente, se la trata, según expresa la Directiva sobre Prácticas Comerciales Desleales de 2005, como una actividad más de las que constituyen las prácticas comerciales de las empresas en sus relaciones con los consumidores (art. 2.d) ${ }^{14}$. Pero eso no significa que se deba desdeñar su otra dimensión, como manifestación iusfundamental que puede entrar en conflicto con los derechos de la esfera personal de los destinatarios del mensaje publicitario. El problema es que su reflejo en las normas comunitarias, aunque se puede apreciar en ocasiones, acaba por resultar testimonial. Por tanto, cabe preguntarse si el Ordenamiento europeo ofrece un marco adecuado en relación a esta cuestión, empezando por la forma en la que las distintas normas caracterizan al sujeto protegido cuando se habla de comunicaciones comerciales.

cance de los derechos garantizados significa que esto deberá realizarse «no sólo por el texto de estos instrumentos, sino también por la jurisprudencia del Tribunal Europeo de Derechos Humanos y por el Tribunal de Justicia de la Unión Europea».

11 STEDH, Casado Coca c. España, 24 de febrero de 1994, § 35. En el Ordenamiento español esta doctrina ha sido recibida tanto por el Tribunal Supremo, teniendo como ejemplo más claro la STS, Sala de lo Civil, de 15 de enero de 2010 (ROJ: STS 444/2010) como, de un modo menos intenso, el Tribunal Constitucional en su Auto 241/2003, de 14 de julio, FJ 6. ${ }^{\circ}$.

${ }^{12}$ Ya que esa función, antes que a la libertad de expresión, se atribuye realmente a la libertad de prensa, entendida como un derecho más específico que comprende la transmisión de información veraz de interés para el debate público. Vid. F. VALDÉs DAL-RÉ, «Artículo 11. La libertad de expresión e información», en La Europa de los derechos. Estudio sistemático de la Carta de los Derechos Fundamentales de la Unión Europea, ed. por C. MonEReo Atienza y J.L. Monereo PÉrez (dirs.), (Granada: Comares, 2012), 235-236.

13 Azurmend, Derecho..., 315.

14 Directiva 2005/29/CE, del Parlamento Europeo y del Consejo, de 11 de mayo de 2005. 


\section{LA INADECUACIÓN DEL CONCEPTO DE CONSUMIDOR PARA DEFINIR AL SUJETO PROTEGIDO POR LAS NORMAS SOBRE PUBLICIDAD EN EL DERECHO COMUNITARIO}

Antes de entrar a describir las medidas protectoras concretas que el Derecho Comunitario europeo prevé frente a las distintas modalidades publicitarias, se hace necesario entrar en la caracterización que el mismo hace de la figura del consumidor en la medida en que el ámbito subjetivo de protección de las distintas disposiciones se define esencialmente a partir de este concepto. En términos generales, se puede afirmar que tanto en el Derecho originario, incluyendo la propia Carta de Derechos Fundamentales, como en el Derecho derivado el consumidor se concibe, de partida, como un agente económico que debe operar en un mercado eficiente basado en la libre competencia, aunque eso no obsta para que deba obtener una protección más amplia.

La entrada en vigor del Acta Única Europea en 1987 supuso la incorporación de las medidas de protección de los consumidores a las políticas de realización del mercado interior ${ }^{15}$, pero sin definir qué debía entenderse por tales; únicamente se incluyó en el Tratado de la CEE la posibilidad de aprobar medidas de aproximación legislativa entre los Estados miembros que tuvieran por objeto lograr un nivel elevado de protección de los mismos dentro del mercado interior (art. 100A). Más adelante, el Tratado de Ámsterdam profundizó en este particular mediante la incorporación de un art. 129A al TCE, que con el Tratado de Niza se renumeró como art. 153, claro precursor del actual art. 169.1 TFUE. Estos preceptos, aunque siguen sin aportar una noción normativa de consumidor, ya incorporan expresamente ciertos elementos subjetivos en relación a esta figura que permiten pensar en ella como algo más que un operador económico. En ellos se menciona la existencia de ciertos intereses propios de los consumidores más allá de los de tipo mercantil, que deben ser protegidos por el Derecho al máximo nivel frente a posibles lesiones que puedan derivarse de la realización de intercambios de bienes o servicios. Entre estos se encuentran la salud y la seguridad y, en la medida en que sean necesarios para garantizar un correcto desenvolvimiento en la economía de mercado, el derecho a la educación y a la información, elemento que claramente permite al Derecho Comunitario intervenir sobre la actividad publicitaria comercial para proteger a sus destinatarios. No obstante, no se mencionan otros bienes jurídicos de la esfera personal (esencialmente la privacidad) que puedan verse afectados en el marco de una transacción comercial.

Las normas de Derecho derivado sí han concretado qué debe entenderse por consumidor y, como tal, beneficiario de esa protección reforzada, aunque

${ }^{15}$ CAmacho Pereira, La protección..., 66. 
lo han hecho siempre en términos estrictamente mercantiles. La Directiva 85/577/CE, del Consejo, de 20 de diciembre de 1985, referente a la protección de los consumidores en el caso de contratos negociados fuera de los establecimientos comerciales, fue la primera en enumerar los elementos característicos de esta figura mediante una definición que se ha ido consolidando en las normas posteriores hasta llegar a la más reciente Directiva 2011/83/UE, del Parlamento Europeo y del Consejo, de 25 de octubre de 2011, sobre los derechos de los consumidores ${ }^{16}$. Conforme a esta última, se considera como tal a cualquier persona física, nunca jurídica, que en los contratos regulados por la propia norma «actúe con un propósito ajeno a su actividad comercial, empresa, oficio o profesión», siendo esta finalidad de la intervención en el negocio jurídico el elemento determinante para distinguir a un consumidor de quien no merece tal tratamiento. El Tribunal de Justicia ha entendido que esta cláusula debe ser interpretada de manera restrictiva ${ }^{17}$, equiparándola a la satisfacción de las necesidades personales o familiares del sujeto o, más simplemente, al consumo con un objetivo privado de quien no participa en actividades comerciales o profesionales.

Por tanto, conforme al Derecho positivo de la UE, la figura del consumidor se define por exclusión en relación al prestador o proveedor de bienes o servicios, como aquella parte contratante en una relación comercial que no se encuentra en esa posición ni pretende emplear lo obtenido en ella en una nueva transacción con ánimo de lucro. Como tal, es un sujeto que está participando en

${ }^{16}$ Véase las Directivas 85/577/CEE del Consejo, de 20 de diciembre de 1985, referente a la protección de los consumidores en el caso de contratos negociados fuera de los establecimientos comerciales (art. 2); 93/13/CEE del Consejo, de 5 de abril de 1993, sobre las cláusulas abusivas en los contratos celebrados con consumidores (art. 2.b); la ya derogada 97/7/CE del Parlamento Europeo y del Consejo de 20 de mayo de 1997, relativa a la protección de los consumidores en materia de contratos a distancia (art. 2.2); 98/6/CE del Parlamento Europeo y del Consejo de 16 de febrero de 1998 relativa a la protección de los consumidores en materia de indicación de los precios de los productos ofrecidos a los consumidores (art. 2.e); Directiva 1999/44/CE del Parlamento Europeo y del Consejo, de 25 de mayo de 1999, sobre determinados aspectos de la venta y las garantías de los bienes de consumo (art. 12.a); 2002/65/CE del Parlamento Europeo y del Consejo, de 23 de septiembre de 2002, relativa a la comercialización a distancia de servicios financieros destinados a los consumidores (art. 2.d); o la 2008/48/CE del Parlamento Europeo y del Consejo, de 23 de abril de 2008, relativa a los contratos de crédito al consumo (art. 12.a). En el mismo sentido, el art. 17.1 del Reglamento (UE) n. ${ }^{\circ}$ 1215/2012, del Parlamento Europeo y del Consejo, de 12 de diciembre de 2012, relativo a la competencia judicial, el reconocimiento y la ejecución de resoluciones judiciales en materia civil y mercantil, también emplea la misma noción de consumidor.

${ }_{17} \mathrm{Al}$ respecto, vid. CÁMARA LAPUENTE, S., «El concepto legal de «consumidor» en el Derecho privado europeo y en el Derecho español: aspectos controvertidos o no resueltos», Cuadernos de Derecho Transnacional, Vol. 3, n. ${ }^{\text { }}$ 1, (Marzo 2011): 87. 
un negocio jurídico como adquirente o ya lo ha perfeccionado, lo cual no se ajusta a la realidad de la relación publicitaria, donde el destinatario del mensaje comercial aún no ha establecido un vínculo contractual con el anunciante. Desde la perspectiva de la comunicación publicitaria resulta más correcto, como hace la Legislación española ${ }^{18}$, hablar de «destinatarios de la publicidad» que de «consumidores» ${ }^{19}$, como dos categorías distintas que, si bien pueden coincidir en la misma persona, no necesariamente han de hacerlo. Al reducir la primera a la segunda, se estaría privando de la posibilidad de ejercitar sus derechos a aquellos receptores efectivos de mensajes publicitarios que no se conviertan finalmente en adquirentes de bienes o servicios.

Por ello, cabe plantearse si resulta adecuado que la titularidad de las garantías que se prevén para las comunicaciones comerciales se defina en las distintas Directivas únicamente a partir del concepto de consumidor, especialmente mediante las referencias que se hacen al «consumidor medio». En este sentido, la doctrina, a partir de los términos que emplea la Legislación española, ha definido al receptor del mensaje publicitario como aquella persona que, o bien es su destinatario directo, o bien simplemente lo recibe, mereciendo protección jurídica desde el momento en el que algunos de sus derechos o intereses legítimos se vean afectados por el mismo ${ }^{20}$. Por ello hay que tener en cuenta que, en el ámbito de la publicidad, la protección se debería dirigir al futuro posible adquirente de bienes o servicios, tal y como planteó en su momento, en relación a obligación de veracidad de la información publicitaria, el Programa preliminar de la Comunidad Económica Europea para una política de protección e información de los consumidores de $1975^{21}$; en éste se hablaba del «adquiriente en potencia del producto o del servicio» como destinatario de la protección, concepto que, sin embargo, no se trasladó al Derecho positivo, que ha optado por la simplificación al emplear una única denominación para designar dos situaciones diferentes.

18 A este respecto, el art. 2 de la Ley 34/1988, de 11 de noviembre, General de Publicidad, considera destinatarios de las comunicaciones publicitarias a «las personas a las que se dirija el mensaje publicitario o las que éste alcance». En el mismo sentido, la Ley 7/2010, de 31 de marzo, General de la Comunicación Audiovisual, emplea los términos «público destinatario» (art. 2.33) o «espectador» (art. 14.3) para identificar a los receptores de las comunicaciones comerciales.

19 Vid. M. Santaella LóPez, Derecho de la publicidad, (Madrid: Thomson-Civitas, 2003), 141-142.

20 S. Vilajoana Alejandre y J. Cuerva de Cañas, ¿Cómo aplicar..., 40.

${ }^{21}$ Aprobado por la Resolución del Consejo, de 14 de abril de 1975, D.O. n. ${ }^{\circ}$ C-092 de 25 de abril de 1975, p. 1, y cuyo enunciado fue reiterado por la Resolución del Consejo de 19 de mayo de 1981, relativa a un segundo programa de la Comunidad Económica Europea para una política de protección e información a los consumidores. D.O. n. ${ }^{\circ} \mathrm{C}-133$ de 03 de junio de 1981, p. 1. 
Así, para mantener la coherencia de las distintas normas europeas en materia de publicidad y no restringir su aplicabilidad hasta el punto de la inoperancia, las referencias que contienen al «consumidor» deberían entenderse realizadas al «potencial consumidor» del bien o servicio objeto del mensaje publicitario. Lo mismo resulta extensible a la caracterización del «consumidor medio» llevada a cabo por el Tribunal de Justicia, más teniendo en cuenta que esta noción se ha construido, precisamente, en relación a la posibilidad de una marca o mención publicitaria de inducir a error o producir un efecto engañoso. Si bien se ha entendido por tal a aquel consumidor «normalmente informado y razonablemente atento y perspicaz $\rangle^{22}$, es su expectativa creada en relación al contenido del mensaje comercial lo que resulta determinante para saber si éste contraviene las reglas del mercado ${ }^{23}$. De ahí se puede inferir que el término se está empleando en sentido impropio en las normas, mal adaptado a las características del ámbito publicitario, como sinónimo de un eventual adquirente futuro del producto que ve su decisión condicionada por una información falsa. En la misma línea, varias Sentencias del Tribunal General han venido equiparando en los últimos años el concepto de «consumidor medio» con el de «público interesado» ${ }^{24}$, que, en función del producto, puede estar compuesto por «todos los consumidores» de manera inespecífica, siempre que sean receptores del mensaje y futuros adquirentes del bien o servicio.

Pero si bien es cierto que la jurisprudencia europea ha definido al sujeto de protección de las normas sobre publicidad construyendo un concepto de consumidor donde se incluye no sólo el adquirente presente, sino el posible, lo cierto es que no ha terminado de desligarlo de su dimensión estrictamente comercial, también condicionada por la competencia material de los propios órganos jurisdiccionales. En lo que respecta al control sobre la actividad publicitaria bajo los términos del sistema de libre mercado instituido a partir de los Tratados esto resulta suficiente, pero no lo es bajo el prisma de la necesidad de proteger la esfera personal de los receptores de comunicaciones comerciales. Porque más allá del interés estrictamente económico, el contenido o forma de un mensaje publicitario, entendido como un ejercicio de las libertades comunicativas. Su alcance, que trasciende a los potenciales interesados en cada producto o servicio, puede incidir en múltiples derechos consagrados por la CDFUE, especialmente el derecho a recibir información veraz del art. 11, que debe ser protegido con independencia de que la

${ }^{22}$ Sentencia del Tribunal de Justicia, caso Gut Springenheide, de 16 de julio de 1998, asunto C-210/96, $\S 31$.

23 Ibidem..., 37.

${ }^{24}$ L. GONZÁLEZ VAQUÉ, «La noción de consumidor medio según la jurisprudencia del Tribunal de Justicia de las Comunidades Europeas», Revista de Derecho Comunitario Europeo, n. ${ }^{\circ} 17$ (Enero-Abril 2004): 74 y s. 
información falseada se materialice o no en un engaño que suponga un perjuicio económico para su receptor.

En el Derecho derivado, el control de la publicidad se articula en función del producto, lo que suele traducirse en prohibiciones a la publicidad de ciertas categorías de bienes o servicios ${ }^{25}$, o bien en relación al medio en el que se desarrolle la comunicación comercial, planteando medidas que condicionan el ejercicio mismo de ésta o la definición de sus objetivos. En el primer caso las restricciones se dirigen a evitar que una difusión generalizada del mensaje alcance a determinados sujetos que, por sus condiciones ni son ni se considera que deban ser consumidores de los productos o servicios anunciados, por lo que los beneficiarios de la protección son, justamente, aquellos que no tienen esa condición. En el segundo, esta finalidad se entremezcla con la de naturaleza estrictamente mercantil, en la medida en que las restricciones buscan tanto que no se produzcan alteraciones en el comportamiento económico de los potenciales adquirentes derivadas de información falsa o manipulada como evitar que la publicidad de determinados bienes o servicios alcance a determinados segmentos de población al realizarse a través de instrumentos o mecanismos que no discriminan entre destinatarios.

En suma, aunque el concepto de consumidor no tiene en el Derecho Comunitario un sentido unívoco ${ }^{26}$, sí está limitado semánticamente en cuanto

${ }^{25}$ Paradigmático en este sentido es el caso del tabaco (Directiva 2003/33/CE del Parlamento Europeo y del Consejo, de 26 de mayo de 2003), cuya publicidad queda prohibida tanto en la radio como en los medios de comunicación de la sociedad de la información, así como en prensa con excepción de las publicaciones destinadas exclusivamente a los profesionales del comercio del tabaco y las publicaciones impresas y editadas en terceros países que no estén destinadas principalmente al mercado comunitario. Lo mismo sucede con los medicamentos que sólo puedan dispensarse con receta, contengan psicotrópicos o no hayan obtenido autorización de comercialización (Directiva 2001/83/CE del Parlamento Europeo y del Consejo, de 6 de noviembre de 2001). En el caso de los alimentos, las restricciones se imponen al contenido de las comunicaciones comerciales, condicionando la información que puede formar parte de la misma y vetando ciertas prácticas consideradas engañosas (Directiva 2000/13/CE del Parlamento Europeo y del Consejo, de 20 de marzo de 2000). La publicidad de bebidas alcohólicas no es objeto de un acto normativo propio, pero sí de medidas específicas en la Directiva de Servicios de Comunicación Audiovisual, donde se prohíbe que se dirija específicamente a menores, fomente su consumo inmoderado o aparezca vinculada a valores positivos como el éxito social o la mejora del rendimiento físico, además de no deber presentar una imagen negativa de la abstinencia o de la sobriedad ni subrayar como cualidad positiva de las bebidas su alto contenido alcohólico. Respecto de las actividades de juego y apuestas, la ausencia de regulación a nivel europeo de sus distintos aspectos, incluyendo la publicidad, contrasta con la necesidad de la misma que se ha puesto de manifiesto por parte del Parlamento Europeo (Vid. Resolución del Parlamento Europeo, de 10 de septiembre de 2013, sobre el juego en línea en el mercado interior).

${ }^{26}$ GonzÁlez Vaqué, «La noción..., 50. 
a forma de caracterizar a un concreto operador económico en relación a la contratación. Sin embargo, el alcance de la actividad publicitaria es más amplio, por lo que sus límites normativos no pueden pivotar en exclusiva sobre él. Al hacerlo, aquellas disposiciones contenidas en las distintas Directivas que, en principio, protegerían intereses de naturaleza no económica y, por tanto, no relacionados con la noción de consumidor, ven reducida y condicionada su eficacia en función de las consecuencias que la vulneración concreta produzca en el comportamiento del sujeto como agente económico. De ahí que resultaría más apropiado que las normas europeas sobre publicidad se dirigieran a la protección de todos los ciudadanos como sujetos de derechos fundamentales frente al ejercicio de la libertad de expresión publicitaria, planteando límites a ésta directamente a partir de las previsiones de la CDFUE. Por el contrario, la identificación del sujeto protegido con la categoría de «consumidor» que las Directivas vigentes realizan tanto en su articulado como en sus exposiciones de motivos, y que la jurisprudencia sólo ha matizado parcialmente, resulta incompleta, pues permite justificar las restricciones a la publicidad destinadas a asegurar el correcto desenvolvimiento del tráfico jurídico, pero no las demás previstas, que sólo se explican desde la perspectiva de la concurrencia de derechos.

\section{LA PROTECCIÓN GENÉRICA FRENTE A LA PUBLICIDAD DESLEAL}

La primera norma de referencia en lo que respecta al tratamiento jurídico de la publicidad en la Unión Europea es la ya citada Directiva sobre Prácticas Comerciales Desleales de 2005. En ésta se establecen una serie de reglas orientadas, conforme a su art. 1, a «contribuir al buen funcionamiento del mercado interior y alcanzar un elevado nivel de protección de los consumidores» frente a «las prácticas comerciales desleales que perjudican a los intereses económicos de los consumidores»; éstas pueden darse, como recoge el art 3.1 «antes, durante y después de una transacción comercial en relación con un producto», lo que permite incluir en el ámbito de aplicación de la norma a la publicidad, concebida en principio como elemento precontractual que puede incidir en la finalización del negocio jurídico ${ }^{27}$.

La finalidad de la norma es proteger al consumidor (potencial o futuro cuando se trata de actuaciones publicitarias) frente a aquellas actuaciones que contradicen los requisitos de la diligencia profesional y distorsionan o puede distorsionar «de manera sustancial, con respecto al producto de que se trate, el comportamiento económico del consumidor medio al que afecta o al

${ }^{27}$ CAmacho Pereira, La protección ..., 79. 
que se dirige la práctica o del miembro medio del grupo, si se trata de una práctica comercial dirigida a un grupo concreto de consumidores» (art. 5.2), debiendo existir una relación directa entre la acción y el efecto ${ }^{28}$. Con ello se busca proteger una de las dimensiones de la actividad comercial, la relación de la empresa con el destinatario final de los bienes o servicios ofertados, mientras que las medidas orientadas estrictamente a asegurar el interés de comerciantes y competidores, de vertiente puramente económica y esencialmente relacionadas con la libertad de empresa, se plasman en la Directiva sobre Publicidad Engañosa y Comparativa ${ }^{29}$.

En primer término queda prohibida la publicidad engañosa. Se trata de aquella que, con la finalidad de engañar al destinatario del mensaje, contenga información falsa o que induzca o pueda inducir a error al consumidor medio (lo que incluye la publicidad comparativa o cualquier manifestación publicitaria que busque confundir el propio producto o servicio con el de un competidor); también la que, considerando el contexto, omita información sustancial o la ofrezca de manera poco clara, ininteligible, ambigua o en un momento que no sea el adecuado, o la que no dé a conocer su propósito comercial. Para ser considerado engañoso, el mensaje publicitario debe hacer, o poder hacer, adoptar al destinatario una decisión sobre una transacción que de otro modo no hubiera tomado como consecuencia de su idoneidad para lograr tal fin ${ }^{30}$. Pero además, conforme a la Directiva, sólo se reputará como desleal, y por tanto será objeto de las medidas previstas en la misma, cuando, adicionalmente, esa decisión se materialice o pueda materializarse en una actuación contractual (un «comportamiento económico»). Si esto no se produce, es decir, si el receptor del mensaje engañoso no adquiere o es conducido a adquirir un bien o servicio como consecuencia directa de la información alterada contenida en la comunicación comercial recibida, resulta irrelevante que ésta haya podido producir en aquel cualquier otra lesión de alguno de sus derechos o intereses legítimos ${ }^{31}$, lo cual no deja de resultar llamativo si se tiene en cuenta que la base de la conducta antijurídica es precisamente la existencia de una vulneración de un derecho fundamental del receptor como es el relativo a recibir información veraz aplicado a un ámbito concreto.

La Directiva sobre Prácticas Comerciales Desleales consagra el principio de veracidad en la publicidad en atención a su función económica. Así

28 J. MASSAGUER FuENTES, El nuevo derecho contra la competencia desleal: la Directiva 2005/29/CE sobre las prácticas comerciales desleales, (Cizur Menor: Thomson-Civitas, 2006), 20.

${ }^{29}$ Directiva 2006/114/CE del Parlamento Europeo y del Consejo, de 12 de diciembre de 2006.

${ }^{30}$ Massaguer Fuentes, Supra... 79.

31 Ibidem..., 30. 
entendido, si bien es cierto que las comunicaciones comerciales no pueden prescindir de un elemento persuasivo, en mensaje que las conforma sí debe cumplir con ciertas pautas de objetividad y estar conformado por información completa y suficiente en relación a las características del bien o servicio implicado $^{32}$, que es lo importante a efectos de contratación, con independencia de otros ornamentos o de cómo alteren estos la presentación de la realidad.

Porque este principio parece considerarse sólo de modo instrumental, como mecanismo para proteger «los intereses económicos de los consumidores frente a las prácticas comerciales desleales de las empresas», lo que, además, sirve indirectamente para asegurar la libre competencia entre los operadores comerciales en la medida en que se evita que uno de ellos tome una ventaja injusta. No se puede negar que éste juega un papel capital en relación al orden económico y el tráfico jurídico, pues resulta esencial para su adecuado funcionamiento y, en última instancia, la protección del interés de la colectividad ${ }^{33}$. Pero lejos de acotar su vigencia a la prevención de fraudes en el comercio, su reconocimiento normativo a nivel comunitario debería servir para trasladar a normas concretas la plena vigencia, en este caso en relación a las comunicaciones publicitarias, del derecho a recibir información veraz, recogido en el art. 11 $\mathrm{CDFUE}^{34}$, en relación a todos aquellos ciudadanos a los que llegue el mensaje, que deberían gozar de determinadas garantías. Y para ello debería ser indiferente que sean o no potenciales adquirentes del bien o servicio promocionado ${ }^{35}$. Lo mismo podría decirse en relación a la salud, la seguridad, los intereses generales o, incluso, el principio de no discriminación, cuya vulneración sólo es relevante a efectos de la Directiva cuando con ella se afecte a la autonomía y racionalidad de las decisiones de consumo, por lo que su protección queda en manos de las decisiones autónomas de los Estados ${ }^{36}$.

32 Camacho Pereira, La protección ..., 63.

33 Descalzo González, Principio de veracidad..., 76-77.

${ }^{34}$ Aunque este artículo no describe el contenido de la libertad de información que consagra, la doctrina del TEDH al respecto, que sirve como criterio interpretativo del contenido de los derechos de la Carta Europea según el art. 52.3 de ésta, sí ha consagrado el principio de veracidad como un elemento consustancial de este derecho. Sobre este particular, vid. Isabel SERRANO MAILLO, «El derecho a la libertad de expresión en la jurisprudencia del Tribunal Europeo de Derechos Humanos: dos casos españoles», en Teoría y Realidad Constitucional, n. 28 (2011): 579-596.

${ }_{35}$ Prueba de su importancia es que son varias las normas comunitarias que, al abordar cuestiones específicas que tienen que ver con los consumidores, reiteran la vigencia de este principio de veracidad, como la Directiva 98/6/CE del Parlamento Europeo y del Consejo de 16 de febrero de 1998 relativa a la protección de los consumidores en materia de indicación de los precios de los productos ofrecidos a los consumidores (art. 4), o el Anexo I de la Directiva sobre Prácticas Comerciales Desleales.

${ }^{36}$ Massaguer Fuentes, El nuevo..., 31-32. 
Considerando el carácter plenamente jurídico de la Carta de Derechos ${ }^{37}$, al que se une su función como instrumento interpretativo de las normas de Derecho derivado en las que se afecten derechos fundamentales ${ }^{38}$, la restricción subjetiva y funcional del alcance de las garantías que prevé la Directiva sobre Prácticas Comerciales Desleales resulta difícilmente admisible. Para aceptarla, o bien se asimila el concepto de consumidor a cualquier receptor del mensaje, lo que no deja de ser una interpretación contra legem de la letra de la norma, o bien habría que añadir al Derecho de la Unión nuevas disposiciones complementarias capaces de dispensar en conjunto una protección completa a los ciudadanos frente a cualquier lesión en sus derechos o intereses que pueda derivarse de una comunicación comercial. En ese caso, esta Directiva pasaría a considerarse una norma especial de naturaleza mercantil integrada en un marco normativo que contemplara la dimensión más subjetiva y personal del fenómeno publicitario.

Lo mismo puede decirse en relación a la otra modalidad de publicidad desleal que veta la Directiva de 2005, la «agresiva», en la medida en que se trata de una forma de comunicación que, tal y como se define, puede generar un perjuicio directo y relevante en determinados derechos del receptor que es totalmente independiente de los efectos económicos que se exigen para considerarla contraria a Derecho, por lo que no parece tener sentido condicionar su protección a estos últimos. La publicidad agresiva se identifica en el art. 8 de la Directiva como aquella que, considerando el contexto, merme o pueda mermar de forma importante, mediante el acoso, la coacción, incluido el uso

${ }^{37}$ Desde la aprobación del Tratado de Lisboa, el art. 6 TUE otorga a la CDFUE el mismo valor jurídico que los Tratados, lo cual permitió superar las dudas iniciales en relación a su fuerza normativa. Actualmente, más que una simple guía de actuación para el Tribunal de Justicia, impone al Legislador europeo unos determinados principios y garantías al actuar en desarrollo de los derechos fundamentales, sirviendo de instrumento prefigurador de estos. Vid. las reflexiones que en su momento se hicieron al respecto en A. RODRÍGUEZ DíAz, «Sobre la naturaleza jurídica de la Carta de Derechos Fundamentales de la Unión Europea», Revista de Derecho Político, n. ${ }^{\circ} 51$ (2001): 45 y s.

${ }_{38}$ En la Sentencia del Tribunal de Justicia, caso Schrems, de 6 de octubre de 2015, asunto C-362/14, § 38, y reiterando lo expresado en otros fallos anteriores, el Tribunal determinó la necesidad de que las disposiciones de una Directiva que regulaba directamente una cuestión que, a pesar de su conexión con ámbitos competenciales específicos, podía vulnerar directamente libertades fundamentales (el tratamiento de datos personales en ese caso) debían «ser necesariamente interpretadas a la luz de los derechos fundamentales protegidos por la Carta». Con esta argumentación, el Tribunal plantea que en el momento en que una Directiva tiene relación con un ámbito que puede «afectar negativamente» a las libertades fundamentales, procede recurrir a una interpretación inspirada en las garantías establecidas por la Carta. O. Vid. PolLicino, «La tutela de la privacy digital: el diálogo entre el Tribunal de Justicia de la Unión Europea y las jurisdicciones nacionales», Revista de Estudios Políticos, n. ${ }^{\circ} 173$ (julio-septiembre 2016): 225 y ss. 
de la fuerza, o la influencia indebida, la libertad de elección o conducta del consumidor medio con respecto al producto, haciéndole tomar una decisión sobre una transacción que de otra forma no hubiera tomado. Nuevamente, el resultado económico es un elemento esencial de la conducta, sólo que en este caso, en la medida en que la coacción en este tipo de publicidad implica el uso o la amenaza de la fuerza física o de otra naturaleza ${ }^{39}$, se produce en términos generales una actuación contraria a la libertad del sujeto receptor, que en sí misma constituye un límite a la legitimidad de la persuasión en el ámbito publicitario con independencia de sus consecuencias ${ }^{40}$. Además, si bien el objetivo de esta previsión es proteger la libertad en la formación de la decisión del consumidor, no es menos cierto que en ella subyace la necesidad de amparar otros bienes jurídicos que trascienden la actuación en el tráfico mercantil por su relevancia intrínseca. Por una parte, la libertad de pensamiento del art. 10 CDFUE, que protege la libre construcción de la propia conciencia frente a coacciones, en cualquier circunstancia. También, considerando que estas prácticas agresivas lo son, frecuentemente, por su carácter invasivo de la privacidad de los ciudadanos, conllevan una lesión del derecho al respeto de la misma conforme al art. $7 \mathrm{CDFUE}^{41}$, pudiendo extenderse al derecho a la protección de datos de carácter personal del art. 8 cuando el mensaje comercial se base en el uso de esta clase de información, aunque esto último tiene su máxima expresión, como se verá, en el caso de la publicidad a través de Internet.

\section{LAS GARANTÍAS FRENTE A LAS COMUNICACIONES PUBLICITARIAS AUDIOVISUALES}

El segundo instrumento de Derecho derivado donde se recogen garantías para el destinatario de la publicidad frente a posibles abusos o excesos es la Directiva de Servicios de Comunicación Audiovisual de 2010 ${ }^{42}$, considerada en abstracto como un gran avance por adecuar la regulación a la nueva situación que deriva de la incorporación de las nuevas tecnologías a la transmisión y difusión de servicios de comunicación audiovisual ${ }^{43}$. En ella se contienen ciertas previsiones de mínimos para la publicidad desarrollada a través de redes de comunicaciones electrónicas, especialmente cuando se trate de

\footnotetext{
39 Massaguer Fuentes, El nuevo..., 134.

40 J. Megías Quirós y L. CABrera CAro, Ética y Derecho en la publicidad, (Granada: Comares, 2013), 24.

${ }^{41}$ S. Vilajoana Alejandre, Las leyes de la publicidad, (Barcelona: UOC, 2011), 94. 2010.

${ }^{42}$ Directiva 2010/13/UE del Parlamento Europeo y del Consejo, de 10 de marzo de

${ }^{43}$ M. García Uceda, Las claves de la publicidad, 7. a ed., (Madrid: ESIC, 2011), 465.
} 
servicios de radiodifusión televisiva, aunque su objeto es mucho más amplio, ya que regula el marco común de los términos en los que deben prestarse, en el territorio de los Estados miembros, todos los servicios que empleen dichos soportes y tengan como finalidad informar, entretener o educar al público en general. En suma, se trata de una norma de mínimos que se orienta a establecer unas pautas comunes en relación a los contenidos de las comunicaciones audiovisuales sin abordar la regulación de aquellos aspectos relacionados con la transmisión en sí misma, que se contienen en la Directiva de Acceso de $2002^{44}$. Aunque el aspecto material de las comunicaciones aparece como más relevante que el puramente técnico a la hora de valorar su posible incidencia en la esfera jurídica de los destinatarios, en lo que respecta a la protección de estos no se deberían desconocer los vínculos que existen entre ambos $^{45}$; no obstante, parece que el Derecho comunitario ha tenido más presente esto en la regulación específica de la publicidad en Internet que en la relativa a la que se realiza en los medios que se pueden denominar convencionales, donde el factor económico y la defensa de la competitividad en un sector que se identifica como un mercado específico parecen seguir siendo el elemento esencial para la Unión Europea.

En lo que respecta estrictamente a las comunicaciones comerciales, esta Directiva insiste en ligar la protección a la noción de «consumidor» como destinatario del mensaje, al proclamar la necesidad de que «la publicidad televisiva se someta a un cierto número de normas mínimas y de criterios» para asegurar de forma «completa y adecuada la protección de los intereses de los consumidores como telespectadores» (considerando 83), sin definir ninguna de las dos posiciones subjetivas. Por tanto, de inicio ya se parte de la misma restricción que hace la normativa sobre competencia desleal, pareciendo entender la publicidad como un fenómeno estrictamente económico sobre el que se plantean determinadas restricciones específicas por razón del medio en el que se desarrolla pero también, especialmente, como un recurso crítico de financiación del sistema audiovisual ${ }^{46}$.

La regulación pivota sobre el concepto de «comunicaciones comerciales audiovisuales», que, conforme a la definición del art. 1.h) de la Directiva, abarca cualquier uso de la imagen, con o sin sonido, cuya finalidad sea la promoción directa o indirecta de los bienes, servicios o imagen de una

${ }_{44}$ Directiva 2002/19/CE del Parlamento Europeo y del Consejo, de 7 de marzo de 2002, relativa al acceso a las redes de comunicaciones electrónicas y recursos asociados, y a su interconexión.

45 A. García Castillejo, «El escenario de la convergencia. La regulación de los contenidos audiovisuales», Telos, n. ${ }^{\circ} 85$ (octubre-diciembre 2010): 26.

${ }^{46}$ F. CAMPos Freire, «La nueva directiva europea sobre los medios audiovisuales remueve el mapa de la televisión», Icono 14, n. $^{\circ}$ 9, (junio 2007): 8. 
persona física o jurídica dedicada a una actividad económica que acompañe a un programa o se incluya en él a cambio de una remuneración o contraprestación similar, o bien con fines de autopromoción. Se incluyen expresamente en esta categoría manifestaciones como la publicidad televisiva convencional, el patrocinio, la televenta, el emplazamiento de producto o cualquier otra manifestación comunicativa que tenga iguales objetivos con excepción de la publicidad encubierta. Por esta última se entiende aquella presentación comercial realizada en programas de una manera intencionadamente confusa en cuanto a su naturaleza de modo que pueda inducir al público a error en cuanto a su naturaleza publicitaria, prohibiéndose en todo caso.

Más allá de esto, y sin perjuicio de que los Estados puedan exigir a los prestadores del servicio de comunicación bajo su jurisdicción el cumplimiento de normas más estrictas o detalladas en los ámbitos regulados siempre que sean conformes al Derecho de la Unión (art. 4.1), las comunicaciones publicitarias comparten con cualquier otra manifestación comunicativa que caiga en el ámbito de la Directiva el beneficio del principio de libre desarro1lo. Por tanto, sólo podrá ser restringido por las razones expresamente contempladas, que en el caso de las comunicaciones comerciales se enumeran en el art. 9, sin perjuicio, como especifica el propio texto, de la plena aplicabilidad al sector audiovisual de las garantías que para el consumidor establecen el resto de normas comunitarias, a pesar de que su alcance práctico puede ser menor que las de esta Directiva.

Conforme al citado precepto, la primera condición que debe cumplir la publicidad en el sector audiovisual es la autenticidad: se obliga a que las comunicaciones comerciales en este ámbito sean fácilmente identificables como tales, prohibiendo las de tipo encubierto y aquellas que empleen técnicas subliminales, en lo que, en el fondo, no es más que una proyección del principio de veracidad aplicado al formato del mensaje, extendiendo su alcance. Puesto en relación con la noción de consumidor medio como sujeto protegido, debe entenderse que la finalidad de esta cláusula es evitar que éste altere su comportamiento económico como consecuencia de la influencia ejercida por un mensaje cuya finalidad persuasiva no se percibe razonablemente, para lo cual las comunicaciones comerciales no deben ocultar su intención real bajo una apariencia de información objetiva que pueda inducir a error al potencial consumidor, y tampoco valerse de formatos destinados al ocio o a la información para ello. En relación al patrocinio de espacios audiovisuales, el art. 10 establece la obligación de informar a los espectadores de la existencia de dicha circunstancia, mediante la correspondiente identificación, al tiempo que prohíbe que estos espacios inciten directamente a la compra o arrendamiento de bienes o servicios, en particular, mediante referencias de promoción concretas. Por el contario, cabe pensar que si el ocultamiento de la finalidad comercial del mensaje no es suficiente para evitar que 
el consumidor medio la perciba, no logrando el propósito de alterar sus intenciones en cuanto a la contratación de bienes o servicios, éste será aceptable en los términos de la Directiva.

La protección de los consumidores, entre los que se menciona en esta ocasión a los inversores, $\mathrm{y}$, en última instancia, del correcto funcionamiento del mercado interior aparece también en el art 3.4 de la Directiva de Servicios de Comunicación Audiovisual como una de las razones que permiten a los Estados establecer excepciones a la libre difusión, dentro de la Unión Europea, de retransmisiones audiovisuales a petición generadas en el territorio de la misma. En este caso, no se especifica si para justificar la adopción de esta clase de medidas debe existir un interés económico concreto o podría invocarse la necesidad de proteger los derechos fundamentales del receptor de las comunicaciones, ya que los Estados siempre pueden adoptar medidas más garantistas.

Más allá de estas previsiones, que presentan una clara conexión con la regulación contenida en la norma sobre competencia desleal, el resto de prohibiciones que art. 9 de la Directiva de servicios audiovisuales establece sobre las comunicaciones publicitarias, más que amparar al destinatario como agente estrictamente económico, tienen más sentido dirigidas a la protección de su esfera personal, por lo que su identificación como consumidor se revela inadecuada e incongruente. Además de las estipulaciones concretas para la salvaguarda de los intereses de los menores de edad, lo que se enumeran en él son, por forma y fondo, garantías de intereses subjetivos o colectivos que carecen de dimensión económica y aparecen consagrados en la CDFUE, lo que muestra la debilidad del conjunto de la construcción normativa. Así, la letra c) del precepto establece que las comunicaciones comerciales audiovisuales deberán abstenerse de: atentar contra la dignidad humana, que debería entenderse en los términos del art. 1 CDFUE como un valor absoluto; incluir o fomentar cualquier tipo de discriminación, en lo que sería una concreción del art. 21 CDFUE para una práctica concreta y donde los aspectos económicos son irrelevantes; fomentar comportamientos perjudiciales para la salud y la seguridad, que ya estarían vetados por los arts. 6 y 35 CDFUE; o fomentar conductas gravemente nocivas para la protección del medio ambiente, protegido por el art. 37, que pueden ser llevadas a cabo por un sujeto influido por un mensaje publicitario sin necesidad de que eso implique contratar de modo alguno. La consideración de estas prescripciones como límites a la libertad de expresión publicitaria que se orientan a proteger los derechos y libertades de los demás u objetivos de interés general en los términos del art. 52.1 CDFUE obligaría, finalmente, a someter su desarrollo a los requisitos impuestos por éste: establecimiento por ley y respeto a su contenido esencial.

Teniendo en cuenta la relevancia de los bienes que se erigen como límite a la libertad de expresión publicitaria, puede resultar llamativa la concesión 
que la Directiva realiza en favor de la autorregulación del sector, en una clara apuesta por reforzar la eficacia de las medidas que se adopten al respecto mediante el apoyo activo de los propios prestadores de los servicios implicados, a los que se hace responsables de la eficacia y seguridad de los usua$\operatorname{rios}^{47}$. No obstante, como la propia norma indica, la autorregulación debe entenderse como un método complementario que en ningún caso puede sustituir la intervención del Legislador estatal como responsable último del cumplimiento de los objetivos impuestos por el Derecho comunitario, en este caso la protección del receptor del mensaje publicitario.

\section{LA PUBLICIDAD DESARROLLADA A TRAVÉS DE INTERNET}

La Unión Europea ha dedicado un tratamiento específico a la publicidad en Internet a través, en primer lugar, de la Directiva sobre Comercio Electrónico de $2000^{48}$, donde se regulan, en términos generales, las comunicaciones comerciales cuando constituyan o formen parte de un servicio de la sociedad de la información, particularmente mediante el uso del correo electrónico. Pero lejos de establecer un régimen diferenciado, esta Directiva se dicta sin perjuicio del contenido de todas las demás normas comunitarias que regulan el ámbito publicitario, por lo que todos los condicionantes, restricciones o límites que el Ordenamiento europeo imponga a la libertad de expresión publicitaria también deberán considerarse vigentes en el ámbito digital con la misma intensidad cuando tengan por objeto la protección de la figura del destinatario del mensaje. Así, resulta de plena vigencia todo lo dispuesto por la Directiva sobre las Prácticas Comerciales Desleales y la Directiva de Comunicación Audiovisual. Pero también el contenido de la Directiva sobre Privacidad y Comunicaciones Electrónicas de $2002^{49}$, aplicable al tratamiento de datos personales en relación con la prestación de servicios de comunicaciones electrónicas de cualquier tipo y que, como norma posterior, viene a modificar las previsiones de la Directiva de 2000 en lo que respecta a la publicidad, reforzando la intervención del Derecho Comunitario en relación a los mensajes comerciales que entren en la categoría de $«$ no solicitados $»^{50}$.

47 J.C. GAVARA de CARA y J.M PÉREZ TORnERO, La alfabetización mediática y la Ley General de Comunicación Audiovisual en España, (Barcelona: UOC, 2012), 56.

${ }^{48}$ Directiva 2000/31/CE del Parlamento Europeo y del Consejo, de 8 de junio de 2000.

49 Directiva 2002/58/CE del Parlamento Europeo y del Consejo, de 12 de julio de 2002 .

50 V. Sánchez del Castillo, La Publicidad en Internet. Régimen jurídico de las comunicaciones electrónicas, (Las Rozas: La Ley, 2007), 13. 
El elemento diferenciador de la publicidad realizada a en el entorno digital, sobre todo en el caso de comunicaciones comerciales no solicitadas que emplean medios directos de relación con el destinatario, es la afectación directa del derecho que se recoge en los arts. 16.1 TFUE, 39 TUE y 8 CDFUE: el que asiste a toda persona para la protección de los datos de carácter personal que le conciernan, que deberán ser tratados de modo leal, para fines concretos y sobre la base del consentimiento del afectado o en virtud de otro fundamento legítimo previsto por la ley, así como la obligación de las instituciones comunitarias de actuar para asegurar su protección en el ejercicio de las actividades comprendidas en el ámbito de aplicación del Derecho de la Unión, y en lo que respecta a su libre circulación. Estos preceptos consagran a nivel europeo una garantía sobre el tratamiento de los datos personales, que el Tribunal de Justicia ha ligado a la protección de la vida privada de los ciudadanos, que se aplica a toda información sobre una persona física identificada o identificable ${ }^{51}$.

Pese a la importancia que parece otorgarse a este bien jurídico, que se erige como uno de los principales límites a las libertades comunicativas, en el Derecho comunitario sólo las normas específicas sobre publicidad en Internet lo han contemplado expresamente como tal, seguramente porque las manifestaciones convencionales de la libertad de expresión en este ámbito no son susceptibles de incidir sobre él (salvo casos muy flagrantes). Sin embargo, la publicidad no solicitada se articula, precisamente, en el previo conocimiento por parte del anunciante de los datos de contacto y, eventualmente, los intereses de un destinatario objetivo del mensaje que no ha consentido su cesión. Por tanto, cuando se regula esta cuestión, existe un objetivo directo de naturaleza mercantil, que bien puede ser la garantía de la lealtad en las transacciones digitales ${ }^{52}$. Pero, nuevamente y de manera inevitable, el régimen jurídico de esta clase de publicidad trasciende el ámbito puramente económico, entrando de lleno en una cuestión que atañe a la protección de la privacidad de los ciudadanos, además en un entorno, el digital, donde resulta particularmente sensible.

Quizá por esto, y a pesar de que su Exposición de Motivos sí recurre a la noción de consumidor para justificar la necesidad de someter a la publicidad no solicitada a requisitos más estrictos, el art. 7 de la Directiva de 2000 no discrimina en función del destinatario al obligar a los Estados a garantizar que toda comunicación comercial por correo electrónico de este tipo

${ }_{51}$ Sentencia del Tribunal de Justicia, caso Schecke, de 9 de noviembre de 2010, asuntos C-92/09 y C-93/09, § 52. Este mismo planteamiento se reitera y sirve como fundamento para la resolución de los casos Digital Rights Ireland, de 8 de abril de 2014, asuntos C-293/12 y C-594/12 y Google Spain, de 13 de mayo de 2014, asunto C-131/12.

52 Sánchez del Castillo, La Publicidad..., 9. 
facilitada por un prestador de servicios establecido en su territorio sea identificable de manera clara e inequívoca como tal en el mismo momento de su recepción. Del mismo modo, la posibilidad de inscribirse en listas de exclusión voluntaria queda abierta a cualquier "persona física», sin que se requiera una particular capacidad de intervención en el tráfico mercantil o voluntad al respecto. Junto con esto, el art. 2.e) de la Directiva plantea un concepto bastante laxo, y hasta cierto punto impropio, de consumidor, caracterizándolo a efectos de su aplicación como «cualquier persona física que actúa con un propósito ajeno a su actividad económica, negocio o profesión», lo que permite entender que puede ser considerado como tal cualquier sujeto que, simplemente, recibe una comunicación comercial no solicitada en la medida en que eso implica un modo de «actuar» en el tráfico mercantil.

El resultado final es el alcance general de las previsiones de la Directiva sobre Comercio Electrónico en relación a las comunicaciones comerciales no solicitadas que, por otro lado y a pesar de su carácter intrusivo, no quedan totalmente prohibidas. Lo que se hace es someterlas al principio de autenticidad, igual que al resto de manifestaciones publicitarias, obligando a que sean identificables como tales en cuanto a su naturaleza, no oculten en nombre de quién se hacen y sean fácilmente accesibles, requisitos que deberán tenerse en cuenta especialmente cuando se trate de ofertas promocionales o concursos o juegos de esta índole.

En contraposición, la Directiva sobre Privacidad y Comunicaciones Electrónicas de 2002 parece enfatizar más la protección de las personas y su intimidad que de los datos como elementos objetivos ${ }^{53}$. Su art. 13 además de reiterar la vigencia del principio de autenticidad, prohíbe las comunicaciones comerciales electrónicas no solicitadas (que se denominan «comunicaciones no solicitadas con fines de venta directa», $\mathrm{y}$, en términos coloquiales, spam), así como las desarrolladas mediante llamada automática o fax. Sólo se permiten en dos casos: cuando el emisor tuviera conocimiento de la dirección de correo electrónico del destinatario por razón de una transacción anterior, siempre que se ofrezca la posibilidad de oponerse a ello, o cuando el sujeto haya consentido previamente, de forma libre e inequívoca, la recepción de este tipo de mensajes o no haya solicitado expresamente no hacerlo, en función de lo que establezca cada Estado. Considerando ambas Directivas, a nivel europeo sí parece estructurarse un sistema de mínimos para la protección de la privacidad del ciudadano frente a intrusiones con objetivo publicitario que se separa de la visión estrictamente mercantilista presente en otras normas, dejando en manos de las legislaciones estatales no sólo la fijación de los términos concretos en los que se articulará la protección que exige el

53 J.A. Vega Vega, Contratos electrónicos y protección de los consumidores, (Madrid: Reus, 2005), 364. 
Ordenamiento Comunitario, sino también la posibilidad de reforzar las garantías contra las intrusiones en la intimidad ${ }^{54}$, que bien podrán fundamentar sus medidas directamente en los respectivos preceptos constitucionales que amparen los derechos afectados. Esta circunstancia no es irrelevante, puesto que, en términos formales, la Directiva sobre Comercio Electrónico establece un sistema de control en origen sobre los servicios de la sociedad de la información, responsabilizando a cada Estado miembro de vigilar que los prestadores establecidos en su territorio respeten su legislación nacional al realizar cualquier servicio de este ámbito. En última instancia es cada estado el que decide si admite o no la publicidad no solicitada realizada a través de medios digitales, sin que el destinatario, cuando está en otro Estado, pueda alegar la propia ley nacional para protegerse de lo que considere una intromisión en su privacidad. Por tanto, y a pesar de la armonización normativa y la prohibición general, la capacidad de los sistemas nacionales para proteger la privacidad de los ciudadanos en este ámbito se ve muy reducida en la práctica. Los términos aplicables dependerán del régimen jurídico establecido en el Estado sede del prestador en la medida en que el Derecho Comunitario permite la implementación de niveles y fórmulas de eficacia desigual a pesar de ser el tipo de publicidad que, sin perjuicio de los problemas que puede plantear desde el punto de vista de la privacidad, mayor incidencia puede tener en el funcionamiento del mercado interior.

\section{PREVISIONES ESPECÍFICAS PARA LA PROTECCIÓN DE LOS MENORES DE EDAD}

Es común entre la doctrina considerar que los menores de edad deben ser objeto de protección específica frente al mensaje publicitario; su inmadurez, su especial vulnerabilidad o la necesidad de tutelar su proceso evolutivo para asegurar que el tránsito a la edad adulta se realiza a salvo de influencias negativas justifican la adopción de medidas especiales para limitar la libertad de expresión publicitaria cuando se estime que ésta puede incidir negativamente en la esfera jurídica o el bienestar del niño o adolescente. Junto con esto, no se puede obviar que los menores también participan en el ámbito mercantil, como consumidores en aquellos casos en los que ya gocen de cierta capacidad económica (adolescentes básicamente) o como sujetos que pueden influenciar o condicionar algunas decisiones de consumo de los adultos. Por todo ello, deben ser protegidos frente a injerencias que se consideren perni$\operatorname{ciosas}^{55}$, que pueden proceder de contenidos considerados ilícitos, que son

${ }^{54}$ Ibidem..., 43.

55 Vid. la Decisión 854/2005/CE del Parlamento Europeo y del Consejo, de 11 de mayo de 2005, por la que se crea un programa comunitario plurianual para el fomento de 
los que constituyen en sí mismos delito y son merecedores de sanción por suponer una intromisión ilegítima en los derechos del menor, o de aquellos calificados como nocivos cuando, a pesar de lícitos, se consideren ofensivos o perjudiciales para el desarrollo o el bienestar de éste conforme a los valores culturales, morales, religiosos o sociales de cada lugar ${ }^{56}$.

En la CDFUE, el art. 24 recoge el derecho del menor a la protección y a obtener los cuidados necesarios para su bienestar, que abarca no sólo los aspectos físicos, sino también los aspectos morales o intelectuales, y que será tanto objeto de medidas positivas como un límite a la acción de la Unión y los Estados ${ }^{57}$, no sólo en lo que respecta a su papel como consumidor. El precepto también obliga a considerar su interés superior de manera primordial en todos los actos relativos a la infancia llevados a cabo por autoridades públicas o instituciones privadas, siendo un bien jurídico cuya protección, a pesar de su indeterminación, puede justificar una restricción a una libertad fundamental garantizada por el Derecho originario mientras ésta sea adecuada para la consecución del objetivo propuesto y no vaya más allá de lo necesario, aunque será cada Estado quien, respetando las obligaciones que impone el Derecho Comunitario, deberá precisar los términos de dicha protección ${ }^{58}$. En estos términos, si bien la CDFUE no menciona expresamente la protección de la juventud y la infancia como un límite a cualquiera de las modalidades de ejercicio de las libertades comunicativas, esta conclusión se desprende naturalmente de una lectura omnicomprensiva de la misma ${ }^{59}$.

Pero junto con la necesidad de proteger el interés del menor, y dentro de la propia lógica que sigue la Unión Europea al ordenar las comunicaciones comerciales, las restricciones sobre éstas justificadas en los derechos o el interés del menor no siempre se plantean desde el punto de vista personal.

un uso más seguro de Internet y las nuevas tecnologías en línea. También la Recomendación 2006/952/CE del Parlamento Europeo y del Consejo, de 20 de diciembre de 2006, relativa a la protección de los menores y de la dignidad humana y al derecho de réplica en relación con la competitividad de la industria europea de servicios audiovisuales y de información en línea.

56 Vid. D. LÓPEZ JiMÉNEZ, «La protección de los menores de edad en Internet: el código español PAOS en materia de alimentación como paradigma de buenas prácticas», Revista Boliviana de Derecho, n. ${ }^{\circ} 18$ (julio 2014): 219 y s.

57 A. MANGAS MARTín, «Título III. Igualdad», en Carta de los derechos fundamentales de la Unión Europea. Comentario artículo por artículo, ed. Por MANGAS MARTín, A. (dir.); GonZalo Alonso, L.N. (coord.), (Madrid: Fundación BBVA, 2008), 449.

${ }_{58}$ Sentencia del Tribunal de Justicia, caso Dynamic Medien Vertriebs, de 14 de febrero de 2008, asunto C-244/06, § 42 a 45.

59 J.M. MARTínez Otero, «La protección de los menores en la política audiovisual de la Unión Europea: un objetivo prioritario», Revista de Derecho Politico, n. ${ }^{\circ} 84$, (mayoagosto 2012), 506. 
Esto es particularmente visible en la Directiva sobre las Prácticas Comerciales Desleales, donde los menores de edad simplemente constituyen un grupo vulnerable a efectos de valorar, desde el punto de vista de la media de sus integrantes, la capacidad de una determinada acción publicitaria para alterar el comportamiento económico de sus destinatarios a efectos de considerarla o no desleal.

La Directiva de Servicios de Comunicación Audiovisual es, en principio, más generosa en el desarrollo de esta cuestión, planteando tres categorías de medidas protectoras ${ }^{60}$ : principios básicos para su protección frente a las comunicaciones comerciales, restricciones relativas o absolutas sobre la publicidad de ciertos productos que se consideran inapropiados o peligrosos para este colectivo y normas sobre los aspectos formales del mensaje publicitario, todas ellas alineadas con la protección el interés subjetivo o personal de los menores. Así, planteando como premisa la necesidad de «equilibrar cuidadosamente las medidas para proteger a los menores y la dignidad humana con el derecho fundamental a la libertad de expresión consagrado en la Carta de los Derechos Fundamentales de la Unión Europea», se impone que las comunicaciones comerciales audiovisuales no deberán producir perjuicio moral o físico a los menores según art. 9.1 de la Directiva, afirmación que debe ponerse en relación con el art. 27.1 de la propia norma cuando, en términos generales, establece que deben evitarse contenidos audiovisuales que puedan perjudicar seriamente el desarrollo físico, mental o moral de los menores, especialmente los basados en pornografía o violencia gratuita. Sin embargo, esta previsión se complementa en el mismo art. 9 con una serie de ejemplos donde adquiere más relevancia el posible condicionamiento del comportamiento económico del receptor que la influencia en su correcto desarrollo: la publicidad dirigida a menores no les deberá incitar directamente a la compra o arrendamiento de productos o servicios aprovechando su inexperiencia o credulidad, ni los animará directamente a que persuadan a sus padres o terceros para que compren los bienes o servicios publicitados, ni explotará la especial confianza que depositan en sus padres, profesores u otras personas, ni les mostrará sin motivo justificado en situaciones peligrosas. Además, se veta expresamente que la publicidad de bebidas alcohólicas se dirija a menores o los muestre consumiéndolas (art. 9.1), prohibición que se suma a las que sobre otros productos (tabaco, medicamentos y tratamientos médicos únicamente disponibles con receta) realizan sus normas específicas, así como la técnica del emplazamiento de producto en programas infantiles por lo difícil que resulta identificarla por parte de los televidentes ${ }^{61}$ (art. 11.2), y se determina que las interrupciones para

${ }^{60}$ Ibidem..., 511.

${ }^{61}$ Con la excepción de los casos en que no se produce ningún pago, sino únicamente el suministro gratuito de determinados bienes o servicios, como las ayudas materiales a la 
espacios publicitarios en este tipo de programas no podrán realizarse en intervalos menores de 30 minutos (art. 20.2).

El resultado de todo esto es un conjunto normativo donde se entremezclan, como aspectos inseparables, medidas destinadas a salvaguardar la integridad física o moral de los menores y otras cuyo fin, además de protegerlos frente a contenidos potencialmente nocivos para su desarrollo, es el de evitar que los operadores económicos utilicen de manera interesada a la juventud y la infancia para mejorar su posición o alterar la competencia. Con ello se corre el riesgo de que este segundo grupo de previsiones acabe por desvirtuar las primeras, dando la falsa impresión de que el menor sólo es relevante como sujeto que consume, y no como persona que debe desarrollarse para alcanzar la condición de ciudadano pleno y libre.

En lo que respecta a la publicidad en Internet, la Resolución del Parlamento Europeo, de 20 de noviembre de 2012, sobre la protección de los niños en el mundo digital planteó la necesidad de que la publicidad dirigida a menores debía ser responsable y moderada (Considerando S), alertando del riesgo que Internet supone para estos al exponerlos, entre otras cosas, a publicidad agresiva, engañosa o inapropiada para la edad (par. 13), por lo que se solicitó a la Comisión priorizar la protección de los niños contra la publicidad insistente o engañosa en televisión y en Internet (par. 23) y desarrollar estrategias y normas que protejan a los menores de la publicidad que fomenta el gasto excesivo por considerarla un contenido inapropiado para su edad (par. 48). Sin embargo, estas inquietudes del Parlamento no se han trasladado al Derecho positivo, donde las medidas concretas para controlar la publicidad en Internet son escasas. La protección de los menores de edad, tal y como se conciba en el Estado que lo plantee, es también una de las justificaciones válidas para restringir tanto la libre circulación de contenidos audiovisuales cuando el control de origen sea deficiente o irresponsable (art. 3 de la Directiva de Servicios de Comunicación Audiovisual) como, a tenor de la Directiva sobre Comercio Electrónico, los servicios de la sociedad de la información que procedan de otro Estado miembro. El problema es que esta última es la única previsión específica en relación a la protección de la juventud y la infancia que se recoge en la regulación de las comunicaciones comerciales que se desarrollen mediante estos servicios. Ni la Directiva sobre Comercio Electrónico ni la de Privacidad y Comunicaciones Electrónicas plantean sobre la publicidad no solicitada límites basados en ese bien jurídico, aunque igualmente sean aplicables los ya expuestos.

De hecho, la primera parece derivar la cuestión al ámbito de la autorregulación del sector cuando señala como objetivo el fomento de los códigos de

producción o los premios, con miras a su inclusión en un programa, respecto de los que los Estados podrán decidir libremente su prohibición conforme al art. 11.3 de la Directiva. 
conducta en materia de protección de los menores y de la dignidad humana (art. 16.1.e)). No obstante, si los principios de autenticidad y accesibilidad que sí contemplan estos textos se ponen en relación con el art. 5.3 de la Directiva sobre Prácticas Comerciales Desleales, se podría reputar como desleal toda comunicación comercial no solicitada que se dirija a menores de edad y sea de tipo encubierto o no se presente de manera que su naturaleza resulte especialmente identificable para ellos y distinguible de otro tipo de contenidos, ya que puede conducir a equívocos considerando la capacidad de juicio de los destinatarios. No obstante, para ello tendría que producirse una distorsión en el comportamiento económico del consumidor menor medio o de aquellos sobre los que éste puede ejercer influencia suficiente. La misma consideración procede respecto de aquellos mensajes publicitarios no solicitados que, por no desarrollar las condiciones relativas al consentimiento para su recepción o al procedimiento para su exclusión en términos accesibles para los destinatarios, conduzcan a idéntico resultado.

Más allá de esto, la principal carencia que el Derecho Comunitario presenta cuando se trata de la protección de los menores de edad ante el mensaje publicitario en el entorno digital parte de la exclusión del ámbito regulado de las comunicaciones comerciales elaboradas de forma independiente del anunciante, y en particular si se realizan sin contrapartida económica ${ }^{62}$. Se renuncia así a abordar el problema que plantean las campañas publicitarias virales, donde la difusión de la comunicación comercial se logra gracias a la fidelización de los destinatarios que, sin contraprestación, adoptan como propio y propagan voluntariamente un mensaje en el que la intención persuasiva aparece disimulada en lo que parece una recomendación bienintencionada o un ejercicio de entretenimiento ${ }^{63}$. Esta modalidad de publicidad encuentra en Internet el medio idóneo para su desarrollo y, aunque no llegue a constituir un supuesto de publicidad subliminal, se basa en campañas que presentan una intención prescriptiva encubierta y una gran capacidad para alterar el comportamiento de sus receptores, sobre todo en el caso de menores de edad. Particularmente si son adolescentes, un colectivo cuyos miembros no sólo carecen de

${ }^{62}$ Así hace el art. 2.f) de la Directiva sobre Comercio Electrónico, al sustraer de la definición de comunicaciones comerciales, y por tanto de su ámbito de aplicación, aquellas «relativas a los bienes, servicios o a la imagen de dicha empresa, organización o persona, elaboradas de forma independiente de ella, en particular cuando estos se realizan sin contrapartida económica».

${ }^{63}$ Para más detalle sobre la caracterización de la publicidad viral, Vid. C. DEL PINO, «Nueva era en la comunicación comercial audiovisual: el marketing viral», Pensar la Publicidad, Vol. I, n. ${ }^{\circ} 2$ (2007): 6 y s.; y sobre los problemas jurídicos que plantea esta modalidad de publicidad en relación a los menores, D. Capodiferro Cubero, «La protección de la juventud y de la infancia y la libertad de expresión publicitaria», Derecom, n. ${ }^{\circ} 21$ (2016): 41 y s. 
la madurez necesaria para afrontar críticamente el mensaje, sino que resultan especialmente influenciables y necesitados de referentes a los que imitar y de los que sentirse partícipes como forma de participar en el proceso de socialización. En estas circunstancias, esta modalidad publicitaria, que somete a error a sus destinatarios por la forma en que se presenta ante ellos ${ }^{64}$, muestra un enorme potencial para incidir negativamente en el interés económico y, sobre todo, personal de los menores que reciban los mensajes, sean o no destinatarios objetivos de los mismos, así como en los derechos de aquellos que se presten a intervenir activa y espontáneamente en la corriente promocional mediante el ejercicio de su libertad de expresión. A pesar de ello, no parece ser un problema que el Ordenamiento Comunitario haya considerado relevante.

En suma, actualmente la protección del menor de edad ante la publicidad, se articula a través de un marco jurídico que ha sido calificado por parte del Comité Económico y Social Europeo como «innecesariamente complejo y demasiado confuso» en su Dictamen de $2012^{65}$. Como pone de manifiesto este texto, las normas comunitarias sobre publicidad resultan claramente insuficientes para proteger a los menores de edad como sujetos de derechos ante la actividad publicitaria. No sólo porque se han dictado considerando sólo la competencia sobre mercado interior cuando podrían haberse basado en otras materias o en la propia CDFUE, sino porque son casuísticas en su formulación y laxas en cuanto a su obligatoriedad. Donde deberían ser más estrictas, «se limitan a una recomendación genérica o simplemente a una referencia a códigos de conducta», además de permitir una trasposición minimalista que ha comprometido su eficacia práctica. Por tanto, aunque actualmente no es vista como tal por el Legislador europeo, «la cuestión de la publicidad infantil y juvenil es, ante todo, una cuestión de ciudadanía y de protección de los derechos fundamentales», afirmación que, en los términos pertinentes, puede hacerse extensible a las garantías de todo ciudadano ante la libertad de expresión publicitaria.

\section{VALORACIONES FINALES}

El Derecho Comunitario dispensa a la publicidad un tratamiento jurídico orientado esencialmente hacia sus aspectos económicos, prestando una particular atención a la prevención de las consecuencias distorsionadoras que su empleo pueda tener sobre la libre competencia o el funcionamiento del

${ }^{64}$ SÁnchez del Castillo, La Publicidad..., 235.

${ }^{65}$ Dictamen del Comité Económico y Social Europeo sobre el tema «Un marco para la publicidad dirigida a los niños y jóvenes», de 18 de septiembre de 2012, Diario Oficial de la UE, Serie C, n. ${ }^{\circ} 351$, de 15 de noviembre de 2012. 
mercado. Esto no es reprochable en el caso de una regulación tan específica como la que atañe a la competencia desleal. El problema surge cuando el resto de normas, que deberían articular un alto nivel de protección general frente a los excesos de la actividad publicitaria, se basa en los mismos parámetros, pivotando casi únicamente en la noción de consumidor como agente económico que es susceptible de sufrir un perjuicio patrimonial en su participación en los intercambios de bienes o servicios como consecuencia de la recepción de comunicaciones cuya intención manipulativa excede los límites de lo admisible en el mercado. Esto supone que la protección de determinados intereses subjetivos de los receptores de mensajes comerciales se plantea en términos muy generales, sin bajar del plano de los principios, y de forma subordinada a los efectos que la publicidad tenga en el tráfico mercantil.

La protección de la juventud y la infancia no escapa a esta aproximación. A pesar de la consagración del interés del menor al máximo nivel en los Tratados, como forma de salvaguardar su desarrollo personal, en el trasfondo de los límites normativos que se establecen sobre las comunicaciones comerciales destinadas a menores subyace un enfoque mercantil donde la protección de su interés parece reducirse a la idea de evitar que la inexperiencia propia de la edad perjudique su intervención en el tráfico jurídico o condicione la de sus progenitores. Frente a esto, una aproximación en clave verdaderamente iusfundamental al problema de la publicidad y los menores debería partir de un debate serio donde se empezara cuestionando hasta qué punto resulta adecuado para el desarrollo mental y social del niño el simple hecho de permitir que reciba comunicaciones de naturaleza comercial.

La perspectiva del Derecho Comunitario, aunque no sea errónea, si es reduccionista. Con ella se está obviando la naturaleza de la publicidad como proceso comunicativo y el hecho de que su ejercicio puede afectar a derechos de los ciudadanos o bienes jurídicos subjetivos ajenos al ámbito comercial pero igualmente dignos de protección. Y todo ello a pesar de la existencia de una Carta de Derechos de la Unión Europea que, al estar dotada del mismo valor jurídico que los Tratados constitutivos, contiene preceptos que pueden servir de fundamento directo para la intervención del Legislador comunitario, sobre el que recae un particular compromiso en lo que respecta a la protección de los derechos fundamentales. A ello se une una jurisprudencia reciente del Tribunal de Justicia que, a pesar de no estar exenta de puntos criticables, parece apostar por la utilización de la CDFUE como criterio interpretativo y de contraste de la validez del Derecho derivado.

No obstante, con las normas actualmente vigentes, la adopción de medidas tendentes a asegurar que la actividad publicitaria no atenta contra intereses de naturaleza no mercantil queda, salvo aspectos puntuales, plenamente en manos de las legislaciones nacionales. De este modo, son los Estados los que, 
al trasponer las distintas Directivas, deben compensar o complementar las limitaciones que éstas presentan en la regulación de los límites a la libertad de expresión publicitaria, que no termina de ser tratada como un derecho. En el caso español, por ejemplo, estas carencias se corrigen en parte mediante la vinculación de las normas sobre publicidad, en sus diferentes dimensiones, con los derechos constitucionalmente protegidos. En ocasiones mencionando directamente la vigencia de los derechos de los demás como límites a la libertad de comunicación publicitaria; y en otras, a través de una interpretación conjunta de las normas aplicables por razón del sujeto o interés implicado. No obstante en ciertos ámbitos, como el de la publicidad a través de medios digitales, el Ordenamiento nacional no ofrece una respuesta del todo satisfactoria a los problemas que se plantean, dependiendo la protección de los ciudadanos en exceso de la autorregulación del sector.

La visión estrictamente económica que parece inspirar las distintas normas comunitarias que establecen límites a la comunicación publicitaria encuentra su máxima expresión en la centralidad de la noción de «consumidor» para definir su alcance a pesar de no corresponderse con la realidad de este proceso. En contraposición se debe considerar, al hilo de la tesis mantenida por el TEDH, que el régimen jurídico de la publicidad es en primer lugar una materia que entronca directamente con la cuestión de los límites de las libertades de expresión e información como derecho fundamental. Como tal, la protección debería articularse considerando el derecho de todos los ciudadanos, como potenciales receptores de este tipo de mensajes, a recibir información veraz, siempre con los matices que impone la propia naturaleza de las comunicaciones comerciales, y a no ver vulnerados el resto de sus derechos subjetivos o intereses legítimos, especialmente los relativos a la privacidad o los que puedan resultar de especial relevancia para colectivos específicos.

Por tanto, si el Legislador europeo pretende abordar el régimen jurídico de las comunicaciones comerciales de un modo verdaderamente completo, su intervención regulatoria deberá tener en cuenta los dos ámbitos diferenciados, pero complementarios, que se imbrican para conformarlo, ninguno de los cuales está actualmente desarrollado de modo satisfactorio. El puramente mercantil, articulando medidas que protejan los intereses económicos del potencial adquirente de bienes o servicios, para lo cual se hace necesario repensar el empleo del concepto de consumidor, y el relacionado con la tutela de la esfera personal de los destinatarios potenciales o directos de un mensaje que puede lesionarla, por su conformación o contenido, definiendo sus límites mediante parámetros que no guarden relación con el tráfico mercantil. Eso es lo que debería exigirse a un proyecto político que declara su aspiración de ser algo más que una organización puramente económica basada en la construcción de un mercado común, naturaleza de la que parece no querer terminar de desprenderse. 
TITLE: The Shortcomings of European Regulations on Commercial Advertising Limits

RESUMEN: El Derecho Comunitario aborda la cuestión de las comunicaciones comerciales de manera dispersa en diferentes normas, articulando su régimen jurídico desde una concepción de la publicidad como una actividad que esencialmente se integra dentro de las relaciones de intercambios de bienes o servicios y, como tal, debe cumplir con las mismas reglas que se imponen a toda transacción comercial para asegurar el adecuado funcionamiento del mercado común. No obstante, también se trata de un ejercicio de las libertades comunicativas que puede afectar negativamente a otros derechos de los receptores de dimensión no estrictamente económica, cosa que no se termina de integrar en las normas europeas, sobre todo por la limitación de su alcance a través de la noción de «consumidor».

Palabras Clave: Publicidad, Comunicaciones comerciales, Consumidor, Derechos Fundamentales, Derecho europeo.

ABSTRACT: Community Law deals with the issue of commercial communications in a scattered manner in different regulations, articulating its legal framework by conceiving publicity as an activity mainly integrated in trade relations; as such, it should comply by the current common market rules imposed to any business transaction. However, publicity is also an exercise of communicative freedoms which can negatively affect other, non-economic, recipients' rights, and this is not well integrated in the European regulation thereon, especially because of the limitation of its scope through the concept of "consumer".

KEY WORDS: Publicity, Commercial communications, Consumer, Fundamental Rights, European Law. 